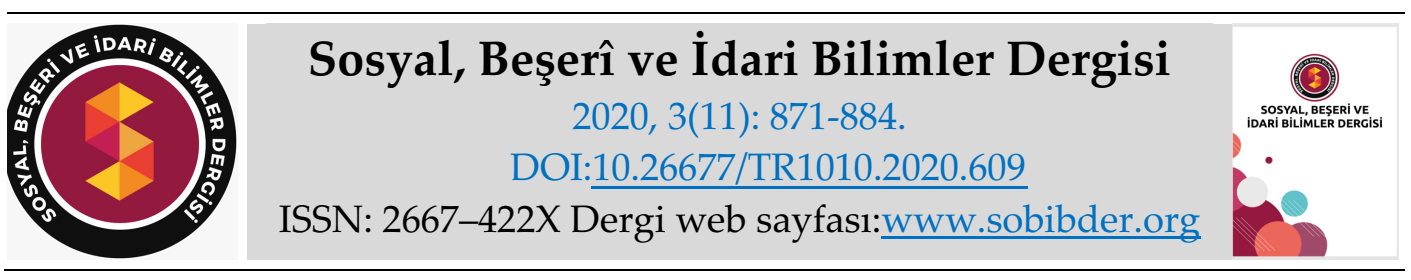

ARASTTIRMA MAKALESI

\title{
Gelişmekte Olan Ülkelerde Reel Döviz Kurları ile Dış Ticaret İlişkisi
}

Dr. Öğr. Üyesi Özhan TUNCAY, İzmir Katip Çelebi Üniversitesi, İktisadi ve İdari Bilimler Fakültesi, İzmir, e-posta: ozhan.tuncay@ikc.edu.tr ORCID: https://orcid.org/0000-0002-5513-2081

Gökmen ÖZKAN, Yüksek Lisans Öğrencisi, İzmir Katip Çelebi Üniversitesi, Sosyal Bilimler Enstitüsü, İzmir, e-posta: gokmenozkan@outlook.com

ORCID: https://orcid.org/0000-0002-6252-2942

Öz

Gelişmekte olan birçok ülkenin gerek makro ekonomik istikrar gerekse de büyüme ve kalkınma amacını gerçekleştirilebilmesi için var olan dış ticaret açılarını finanse edebilmesi gerekmektedir. Döviz kurlarında, sermaye giriş ve çıkışlarına bağlı olarak ortaya çıkan dalgalanmalar ise diş ticareti ciddi oranda etkilemektedir. Mevcut çalışmada döviz kurları ile diş ticaret dengesi arasında bir ilişki olup olmadığının ve varsa bu ilişkinin hangi yönde olduğunun tespit edilmesi amaçlanmıştır. Bu amaçla ekonomik anlamda birbirine benzediği düşünülen dokuz gelişmekte olan ülke analize dahil edilmiştir. Söz konusu ülkelere ait verilerin analizinde 2009 ile 2018 yılları arası dönem seçilmiştir. Feasible Generalized Least Squares (FGLS) yöntemi kullanılarak yapılan analiz sonucuna göre reel efektif döviz kurlarının dış ticaret dengesini pozitif yönde etkilediği saptanmıştır. Analizde yer alan diğer değişkenler olarak reel faiz, doğrudan yabancı yatırımlar, kamu harcamaları ve kişi başı milli gelirin ise dış ticaret dengesini negatif yönde etkilediği tespit edilmiştir. Ele alınan tüm değişkenler yüksek anlamlılık düzeyine sahiptir.

Anahtar Kelimeler: Gelişmekte Olan Ülkeler, Reel Efektif Döviz Kuru, Dış Ticaret Dengesi, FGLS Yöntemi.

Makale Gönderme Tarihi: 05.07.2020

Makale Kabul Tarihi: 03.11.2020

\section{Önerilen Atıf:}

Tuncay, Ö. ve Özkan, G. (2020). Gelişmekte Olan Ülkelerde Reel Döviz Kurları ile Dış Ticaret İlişkisi, Sosyal, Beşeri ve İdari Bilimler Dergisi, 3(11): 871-884.

(C) 2020 Sosyal, Beşerî ve İdari Bilimler Dergisi. 


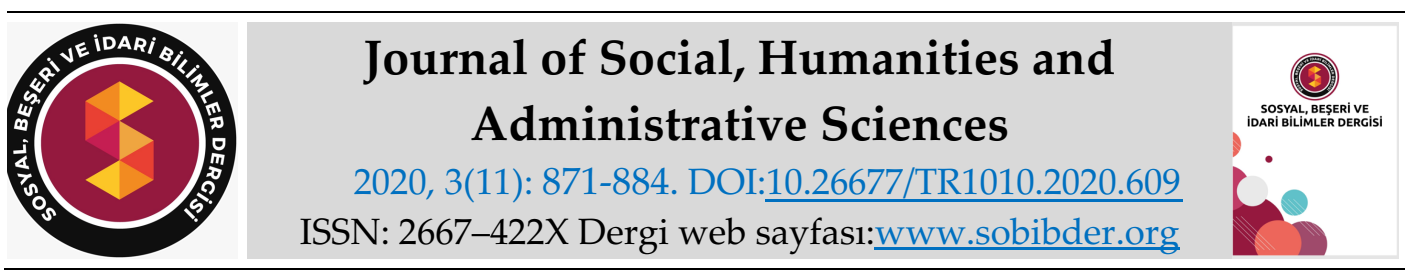

RESEARCH PAPER

\title{
The Relationship Between Real Exchange Rates and Foreign Trade in Developing Countries
}

Assistant Prof. Dr. Özhan TUNCAY, İzmir Katip Çelebi University, Faculty of Economics and Administrative Sciences, İzmir, e-mail: ozhan.tuncay@ikc.edu.tr

ORCID: https://orcid.org/0000-0002-5513-2081

Gökmen ÖZKAN, MSc. Student, İzmir Katip Çelebi University, Social Sciences Institute, İzmir, e-mail: gokmenozkan@outlook.com

ORCID: https://orcid.org/0000-0002-6252-2942

\begin{abstract}
Many developing countries must be able to finance existing foreign trade deficits in order to achieve macroeconomic stability as well as growth and development goals. Fluctuations in exchange rates due to capital inflows and outflows affect foreign trade significantly. In the current study, it was aimed to determine whether there is a relationship between exchange rates and foreign trade balance and which direction of this relationship, if any. For this purpose, nine developing countries, which are considered to be economically similar, are included in the analysis. In the analysis of the data of these countries, the period between 2009 and 2018 was selected. According to the results of the analysis made using the Feasible Generalized Least Squares (FGLS) method, real effective exchange rates were found to positively affect the foreign trade balance. Real interest, foreign direct investments, public expenditures and per capita national income as other variables in the analysis were found to have a negative effect on the foreign trade balance. All variables discussed have a high level of significance.
\end{abstract}

Keywords: Developing Countries, Real Effective Exchange Rate, Foreign Trade Balance, FGLS Method.

Received: 05.07.2020

Accepted: 03.11.2020

\section{Suggested Citation:}

Tuncay, Ö. and Özkan, G. (2020). The Relationship Between Real Exchange Rates and Foreign Trade in Developing Countries, Journal of Social, Humanities and Administrative Sciences, 3(11): 871884.

(c) 2020 Sosyal, Beşerî ve İdari Bilimler Dergisi. 


\section{Gíriş}

Günümüz ekonomik küreselleşme olgusunun gündeme getirdiği temel makroekonomik sorunların başında gelişmekte olan ülkelerdeki cari işlemler dengesi açıkları ve bunun finansmanı ile döviz kurlarındaki istikrarsızlıklar gelmektedir. Buna istinaden özellikle gelişmekte olan ülkeler istikrarlı bir kur politikası yoluyla ekonomik büyüme ihracatı artırmaya çalışmaktadırlar. Çünkü döviz kurlarındaki istikrarsızlıklar yatırım, dış ticaret ve büyüme başta olmak üzere pek çok makroekonomik büyüklüğü de olumsuz yönde etkileyebilmektedir.

Gelişme yolundaki ekonomiler dengeli ve sürekli bir ekonomik büyümeyi temin etmeye yönelik olarak ihracatlarını artırmaya gayret etmektedirler. Bir ulusal paranın döviz kurundaki yükselmenin ihracatı artıracağı şeklindeki genel teorik kabulün bir sonucu olarak pek çok ülke döviz kurlarını ihracatı artırmaya yönelik bir dış ticaret politikası aracı olarak kullanmaktadır. Ancak döviz kurları, ülkelerin dış rekabet güçleri ve ihracat hacminin artırılması açısından tek belirleyici unsur olmayıp; dış ticarete konu olan malların talep elastikiyetleri, ülkenin üretim yapısı, rakip ülkelerin fiyat ve kur politikaları, ürün kalite ve çeşitliliği gibi pek çok faktör bu konuda belirleyici olabilmektedir.

Özellikle gelişmekte olan ülkelerde rekabet gücünün ve ihracat olanaklarının artırılması konusunun oldukça çok boyutla olmasına karşın söz konusu çalışmada döviz kurları ile dış ticaret dengesi arasındaki ilişki boyutu üzerine yoğunlaşması amaçlanmıştır. Bu bağlamda mevcut çalışmada, ekonomik olarak birbirine yakın olduğu düşünülen ve Brezilya, Gürcistan, İran, Malezya, Meksika, Pakistan, Paraguay, Rusya ve Türkiye'den oluşan 9 ülke ve 2009-2018 yıllarını kapsayan dönem için FGLS yönteminden yararlanılarak analiz gerçekleştirilmeye çalışılmıştır. Çalışmada dış ticaret dengesi, kişi başı milli gelir, doğrudan yabancı yatırımlar, reel faiz oranları, reel efektif döviz kuru ve kamu harcamaları değişkenlerinden yararlanılmıştır.

\section{TEORIK ÇERÇEVE}

Günümüzde uluslararası ticarette artan serbestleşme, tarife ve kotalar gibi dış ticaret politikası araçlarının kullanım imkânlarını azaltırken; döviz kurlarını ve kur politikalarını güçlü bir dış ticaret politikası aracı haline getirmiştir. Bu durum özellikle gelişmekte olan ülkeleri hem iç ve hem de dış dengenin eş anlı olarak sağlanmasında ekonomik yapıları ile uyumlu bir döviz kuru politikası izlemeye yöneltmektedir. Çünkü ekonomi politikası amaçları ile uyumlu olmayan bir kur politikası tercihi cari işlemler dengesi açığını büyütüp, ülkeyi bir dış ödemeler krizine sürükleyebilecektir. Dolayısıyla ülkelerin döviz kuru politikalarını oluştururken ülkenin dişa açılık derecesi, devletin ekonomik öncelikleri, üretim yapısı, ülkenin ihraç mallarının çeşitliliği, geçmiş yıllar ve cari yıldaki enflasyon oranı, politik istikrar, ülkenin ve ülkedeki kurumların kredibilitesi gibi unsurları dikkate almaları gerekmektedir (Yağcl, 2001: 1).

Ekonomik ve finansal küreselleşme sürecinin bir sonucu olarak sermaye akımlarının, artan ölçüde ülkelerin dış dengeleri üzerinde etkili olduğu günümüz koşullarında finansal piyasaların gelişmişliği ile döviz kurlarına ilişkin izlenen politikaların başarısı arasında yakın bir ilişki söz konusu olmaktadır. Özellikle para ve sermeye piyasalarının gelişmişliği, finansal piyasalardaki denetim mekanizmasının yeterliliği gibi unsurlar döviz kurlarının istikrarı açısından önem taşımaktadır (Caramazza, 1998: 2). Öte yandan, sermaye mobilitesinin yüksek olduğu ve sabit kur politikasının izlendiği bir ekonomide bankacılık kesimine verilen devlet garantileri, aşırı borçlanma ile birlikte bankacılık krizlerine kaynaklık edebilecektir (Mckinnon, 1999: 1).

Döviz kurlarının belirlenme rejimi ülke ekonomilerinin dış şoklara karşı kırılganlık derecesini de etkilemektedir. Özellikle, ekonominin büyüklügüu, siyasi istikrar, ticaret ortakları, üretim 
potansiyeli ve ürün çeşitliliği gibi faktörler hangi şoklar karşısında ülke ekonomisinin daha kırılgan olduğu konusunda belirleyici olabilmektedir (Aygören; 2014: 21). Özellikle döviz kurlarının piyasada oluştuğu bir sistemde dış şokların olumsuz etkilerinden korunabilmek mümkün olabilecekken; kurların belli seviyede istikrarlı olarak tutulduğu bir sistemde ise içsel şoklardan korunmak daha mümkün olabilecektir (İnan, 2002: 43).

Kronik enflasyon problemi olan ülkelerde döviz kurlarının oluşumu ülkenin dış dengesi açısından önem kazanmaktadır. Şöyle ki kurların enflasyon oranından daha düşük bir oranda yükseldiği ya da bir istikrar programında nominal çapa olarak kullanıldığı ekonomilerde ulusal para aşırı değerlenerek cari açık büyümekte ve olası bir krizi tetikleyebilmektedir.

Döviz kurlarının oluşumunda dış ticaretin ne ölçüde çeşitlendirildiği de önem kazanmaktadır. Şöyle ki, ihracatın tek ya da az sayıda ülke ile sınırlı olması, söz konusu pazarlarda ortaya çıkabilecek sorunlar karşısında ülkeyi kur riski ile karşı karşıya bırakabilecek; ihracat yapılan pazarların çeşitlendirilmesi ise kur riskini azaltacaktır (Eichengreen, 1998: 23). Benzer biçimde dış ticarette ürün çeşitliliğinin sağlanması, dış ticaret hadlerindeki değişimden kaynaklı riskleri azaltabilecektir.

Ülke yerleşiklerinin ulusal para ile birlikte ya da onun yerine başka bir ülkenin parasını kullanması şeklinde ifade edilen para ikamesi olgusu da döviz kurlarının oluşumunu etkilemekte; merkez bankasının para ve kur politikası uygulayabilme olanaklarını sınırlandırdığ gibi, döviz kurlarının kontrolünü zorlaştırarak dış ticarette belirsizliklere sebep olmaktadır (Kansu, 2006: 44-57).

Döviz kurlarının oluşumunda önemli rol oynayan diğer bir faktör de merkez bankası rezervleridir. Çoğu zaman merkez bankasının döviz rezervlerinin yüksekliği döviz kurlarının istikrarının bir güvencesi olarak kabul edilir. Rezervlerin kritik olarak kabul edilen eşiğin altına inmesi ulusal paraya yönelik spekülatif saldırıları tetikleyebileceği gibi; ülkenin döviz yükümlülüklerini yerine getirebileceğine ilişkin kaygıları da artırır. Kurların piyasa mekanizması içerisinde belirlendiği ülkelerde ise döviz rezervine olan gereksinimin daha az olacağı kabul edilmektedir (Kansu, 2006: 44-57).

\section{AMPIRIKK ÇALIŞMA}

Gelişmekte olan ülkelerde sürdürülebilir bir büyüme ve kakınma açısından dış ticaret dengesinin sağlanması hayati öneme haiz olmaktadır. Finansal sistem ve dış ticaretin dünya genelinde gittikçe serbestleşmesi, ülkeleri dış dengeyi sağlamada döviz kurlarını bir ticaret politikası aracı olarak kullanmaya yöneltmektedir. Seçilen bazı gelişmekte olan ülkelerde dış ticaret dengesini belirleyen faktörlerin araştırılmasının amaçlandığı ampirik analize geçilmeden önce aşağıda konuya ilişkin literatüre değinilmesi düşünülmüştür.

\section{Literatür Özeti}

Döviz kurları dış ticaret ilişkisinin ampirik olarak araştırılmasına yönelik olarak literatürde önemli miktarda çalışma bulunmaktadır. İlk dönem analizlerinden Cooper (1971), 20 ülkeye yönelik olarak gerçekleştirdiği çalışmada, karşılaştırmalı bir istatistik analiz sonucunda, araştırmaya dâhil olan ülkelerin birçoğunda reel döviz kurlarının dış ticaret hadleri üzerindeki etkisinin önemsiz olduğu sonucuna ulaşmıştır.

Spitaler (1980) 1973-78 yılları arasındaki döneme ilişkin on gelişmiş ülkeyi esas aldığı çalışmasında döviz kurlarında kısa dönemli volatilitenin dış ticaret dengesi ve dış ticaret hadleri 
üzerine etkisini araştırmıştır. Analiz sonucunda bir ülke hariç diğer tüm ülkelerde döviz kurlarının değişimi ile dış ticaret hadleri arasında zıt yönlü bir nedensellik ilişkisi bulunduğu görülmüştür.

Edwards (1989) tarafından gerçekleştirilen bir çalışmada ise gelişmekte olan 12 ülke ve panel veri analiz yönteminden yararlanılarak dış ticaret hadleri ile reel döviz kuru ilişkisi araştırılmıştır. Analiz sonucunda dış ticaret hadlerinde ortaya çıkan değişimin reel kurları etkilediği sonucuna ulaşılmıştır.

Rose (1991) çalışmasında 1974-86 yılları arasındaki döneme ilişkin aylık verilerden yararlanarak 5 OECD ülkesinde çalışmada diş ticaret, reel döviz kuru, yurt içi ve yurt dışı gelir arasındaki ilişkiyi araştırmıştır. Çeşitli parametrik ve parametrik olmayan test yöntemlerinin kullanıldığı çalışmada reel döviz kuru ile dış ticaret dengesi arasında anlamlı bir ilişki bulunmadığı sonucuna ulaşmıştır.

Arize (1994) 9 Güneydoğu Asya ülkesini (G. Kore, Malezya, Sri Lanka, Hindistan, Endonezya, Tayland Pakistan, Filipinler, Endonezya, Singapur) ele aldığı çalışmasında, 1973-1991 yılları arası dönemde diş ticaret dengesi ile reel döviz kurları arasındaki ilişkiyi Kointegrasyon yönteminden yararlanarak araştırmıştır. Yapılan analiz sonucunda Hindistan ve Sri Lanka dışındaki ülkelerde uzun dönemde döviz kurlarındaki yükselmenin dış ticaret dengesini olumlu yönde etkilediği sonucuna ulaşılmıştır.

Als ve Oskooee (1995) tarafından gerçekleştirilen ve gelişmiş ve gelişmekte olan 25 ülke için efektif döviz kurları ile diş ticaret hadleri arasındaki ilişkinin koentegrasyon analizi ile test edildiği bir çalışmada uzun dönemde reel efektif döviz kurları ile dış ticaret hadleri arasında bir ilişki bulunmadığı görülmüştür.

In ve Menon (1996) tarafından 7 OECD ülkesi için koentegrasyon ile nedensellik analizlerinden yararlanılarak reel döviz kurları ile dış ticaret hadleri arasındaki ilişki araştırılmıştır. Araştırma sonucunda uzun dönemde ticaret hadleri ile reel döviz kurları arasında negatif yönde anlamlı bir ilişki olduğu tespit edilmiştir.

Shirvani ve Wilbratte (1997) tarafından yapılan bir çalışmada ise, 1973-90 yılları arasını kapsayan dönem için, G-7 ülkelerinde reel döviz kurları ile dış ticaret dengesi arasındaki ilişki araştırılmıştır. Yapılan ampirik analiz sonucunda reel döviz kurlarının kısa vadede dış ticareti etkilemediği, ancak uzun dönemde Marshall-Lerner koşulunun geçerli olduğu ve devalüasyonun dış ticaret dengesini olumlu yönde etkilediği sonucu elde edilmiştir.

Bahmani-Oskoe-Niroomand (1998) 1960-92 yılları arası dönem için 28 ülke ele alarak gerçekleştirdiği çalışmasında Johansen Eşbütünleşme Testi'nden yararlanarak Marshall- Lerner koşulu'nun geçerliliğini test etmiş; analiz sonucunda esneklik şartının ele alınan ülkelerin tamamına yakınında gerçekleştiğini ortaya koymuştur.

Sinha (2001) 1950-97 yılları arasında 5 Güney Doğu Asya ülkesinde Marshall-Lernerşartının geçerliliğini araştırmıştır. Tam Düzeltilmiş En Küçük Kareler Yöntemi'nden (FMOLS) yararlanılan analiz sonucunda birisi dışında analize konu ülkelerin hepsinde Marshall-Lerner şartının sağlandığı görülmüştür.

Lane ve Milesi-Ferretti (2002) 1974-1998 yılları arasında yirmi ülkeye ait verilerden yararlanarak yaptığ 1 çalışmada dış zenginlik, ticaret dengesi ve reel döviz kuru aralarındaki ilişkiyi araştırmış; analiz sonucunda ticaret dengesi ve reel döviz kuru arasında zıt yönlü bir ilişki olduğu sonucuna ulaşılmıştır.

Lal ve Lowinger (2002) tarafından gerçekleştirilen bir çalışmada ise, 1980-1998 yılları arasında üçer aylık verilerden yararlanarak 7 Asya ülkesinde dış ticaret dengesini belirleyen faktörler 
araştırılmıştır. Eşbütünleşme analizi, hata düzeltme modeli ve etki tepki fonksiyonlarından yararlanarak yapılan analiz sonucunda ithalattan ihracat ve döviz kurlarına doğru uzun dönemli bir ilişki olduğu görülmüş ve aynı zamanda J eğrisinin de geçerli olduğu sonucuna ulaşılmıştır.

Onafowora (2003) çalışmasında, 1980-2001 yılları arası dönem için koentegrasyon tekniği ve vektör hata düzeltme modelinden yararlanarak uzun ve kısa dönem için Endonezya, Malezya ve Tayland'ın Amerika Birleşik Devletleri ve Japonya ile olan dış ticaretleri açısından incelemiş; yaptığ 1 ampirik analiz sonucunda reel döviz kuruyla dış ticaret dengesi arasında uzun dönemde kararlı bir ilişki olduğu sonucuna ulaşmıştır.

Liew, Lim ve Hussain (2003) tarafından gerçekleştirilen bir ampirik çalışmada ise, 1986 ile 1999 yılları arası dönemde ve seçili Asya ülkelerinde döviz kuru değişiminin dış ticaret dengesi üzerine etkisi incelenmiş ve kurlardaki değişimin dış ticaret dengesini etkilediği bulgusuna ulaşılmıştır.

Baldemir ve Keskiner (2004) çalışmasında, panel veri analizi yönteminden yararlanarak reel döviz kurundaki değişimin Türkiye'nin Amerika Birleşik Devletleri, Almanya, Hollanda, İngiltere ve İtalya ile olan ticaretine etkisini araştırmıştır. Yapılan ampirik analiz sonucunda ilgili ülkelerin gayri safi yurt içi hâsılalarındaki artışın dış ticaret dengelerini olumsuz yönde etkilediği görülmüştür.

Karagöz ve Doğan (2005) 1995-2014 yıllarına ilişkin verilerden yararlanarak Türkiye'de döviz kurları ile ihracat ve ithalat arasındaki ilişkiyi araştırmıştır. Eşbütünleşme Analizi'nin uygulandığı çalışmada döviz kurları ile ihracat ve ithalat arasında anlamlı bir ilişki tespit edilememiştir. Ancak, 2001 yılında gerçekleştirilen devalüasyonun anlamlı bir etkisi olduğu saptanmıştır.

Halıcıoğlu (2007) tarafından gerçekleştirilen bir çalışmada ise, Türkiye ile başlıca ticaret ortakları arasında 1985-2002 yılları ile 1985-2005 yılları arası dönemler için J Eğrisi'nin geçerliliği eşbütünleşme testi ile araştırılmaya çalışılmıştır. Yapılan ampirik analiz sonucunda, Türkiye ile ticaret ortakları ülkeler arasında J eğrisinin bulunmadığı saptanmış, uzun dönemde ise Türkiye, Amerika Birleşik Devletleri ve İngiltere arasında Marshall-Lerner Koşulu'nun sağlandığ sonucuna ulaşılmıştır.

Vergil ve Erdoğan (2009) 1989-2005 yılları arasındaki dönem için Türkiye'de Marshall- Lerner Koşulu ile kısa dönmede J eğrisinin geçerliliğini sınamaya yönelik olarak yaptıkları çalışmada ADF ve PP birim kök testleri ile ADRL koentegrasyon testinden yararlanmışlardır. Yapılan ampirik analiz sonucunda araştırmaya konu olan dönemde Türkiye'de Marshall-Lerner Koşulu'nun ve J eğrisinin geçerli olduğu sonucu elde edilmiştir.

Alptekin (2009) 1992-2009 yılları arasında Türkiye'de dış ticaret ile reel döviz kuru arasındaki ilişkiyi araştırdığı çalışmasında VAR analizi, Granger nedensellik testi, etki tepki ve varyans ayrıştırma testlerinden yararlanmıştır. Analiz sonucunda reel döviz kurları ile dış ticaret hacmi arasında bir ilişki bulunmadığı görülmüştür.

Hephaktan vd., (2011) tarafından yapılan bir diğer çalışmada ise, 1982-2011 yılları arasında uygulanan döviz kuru rejiminin dış ticaret dengesinin sağlanmasındaki etkinliğini araştırmaya yönelik olarak, Johansen eşbütünleşme ve Granger nedensellik testlerinden yararlanılmıştır. Analiz sonucunda Dış ticaretten reel efektif döviz kurlarına doğru bir nedensellik ilişkisi bulunmuş; ancak reel efektif kurların dış ticaret dengesi üzerinde etkisi olmadığı sonucuna ulaşılmıştır.

Okay vd., (2012) tarafından gerçekleştirilen bir diğer çalışmada, 2003-2010 yılları arası dönemde Türkiye'de reel efektif döviz kurlarının cari işlemler dengesi üzerine etkisini araştırmaya zaman 
serisi analizi yönteminden yararlanılmıştır. Analiz sonucunda reel efektif kurun cari işlemler dengesini uzun dönemde zıt yönde etkileyerek Marshall-Lerner koşulunu sağladı̆̆ı; J eğrisi etkisinin geçerli olduğu görülmüştür.

Göçer ve Elmas (2013) çalışmasında, 1989-2012 yılları arasında Türkiye' de reel döviz kuru ile dış ticaret dengesi arasındaki ilişkiyi araştırmıştır. Çoklu yapısal kırılmalı zaman serisi analizi yönteminden yararlanılan çalışmada tüm mal gruplarında, genişletilmiş Marshall Lerner koşulunun geçerli olduğu sonucuna ulaşılmıştır.

Öncel ve İnal (2016) 2000-2015 yılları arasında Türkiye'de reel döviz kuru ile dış ticaret dengesi arasındaki ilişkiyi ARDL testi yardımıyla araştırdığı çalışmasında reel döviz kuru ile dış ticaret dengesi arasında eşbütünleşme ilişkisinin bulunduğu görülmüştür. Nedensellik ilişkisinin tespitine yönelik olarak yapılan Toda-Yamamoto testi sonucunda reel döviz kurundan diş ticaret dengesine doğru tek yönlü bir nedensellik bulunduğu sonucuna ulaşılmıştır.

Chaudhary vd., (2016) 1979-2010 yılları arasında seçilmiş bazı Güney ve Güneydoğu Asya ülkelerinde ithalat ve ihracat ile döviz kurları arasındaki ilişkiyi araştırmayı amaçlamıştır. Değişkenler arasında kısa ve uzun dönemli ilişkinin araştırılmasına yönelik çalışmada eşbütünleşme ve hata düzeltme modellerine ARDL testi uygulanarak seçili ülkelerin yarıdan fazlasında döviz kuru ile ihracat arasında uzun dönemli bir ilişkinin bulunduğu; ancak döviz kuru ile ithalat arasında sadece bir ülkede anlamlı bir ilişkinin olduğu görülmüştür. Seçili ülkelerin çoğunda kısa dönemde değişkenler arasında anlamlı bir ilişkiye rastlanmamıştır.

Badinger ve Clairfontaine (2018) 2010-2017 yılları arasında 47 ülke ve 97 mal grubu için döviz kurunun dış ticaret dengesi üzerine etkisini araştırdığı çalışmasında J Eğrisi Hipotezi çerçevesinde Yapısal Çekim Modeli'nden yararlanarak döviz kurlarının dış ticaret üzerinde ülkeler ve ürün grupları için farklı etkileri olduğunu belirlemiştir.

\section{Amaç, Yöntem ve Veri}

Benzer ekonomik yapıya sahip olduğu düşünülen seçili bazı gelişmekte olan ülkelerde 2009 ile 2018 yılları arası dönem için reel efektif döviz kurlarının dış ticaret dengesi üzerine etkisinin dış ticaret dengesi üzerinde belirleyiciliğinin olabileceği düşünülen diğer bazı değişkenlerin de modele eklenmesi suretiyle araştırılması çalışmanın amacını oluşturmaktadır. Bu amaçla analize konu ülkeler; Brezilya, Gürcistan, Meksika, İran, Türkiye, Rusya, Pakistan, Paraguay, Malezya'dır. Çalışmada yararlanılan değişkenler ise, reel efektif döviz kuru, dış ticaret dengesi, kamu harcamaları, reel faiz oranı, doğrudan yabancı sermaye, kişi başı milli gelirdir.

Çalışmada ampirik analize yönelik olarak Tahmin Edilebilir En Küçük Kareler Yöntemi'nden (FGLS - Feasible Generalized Least Squares) yararlanılmıştır. Panel veri analizinde hata terimine ait varsayımların gerçekleşmemesi durumunda söz konusu yöntem, bu varsayımlara karşı dirençli tahminciler vermektedir. Genelleştirilmiş en küçük kareler yöntemi, varyans-kovaryans matrisinin bilindiği durumlarda kullanılabilmekte; ancak genellikle varyans-kovaryans matrisi bilinememekte ve tahmin edilmesi zorunlu hale gelmektedir. Bu gibi durumlarda, FGLS yönteminden yararlanılmaktadır (Üstüner, 2017: 59).

Çalışmada ampirik analize yönelik olarak oluşturulan model ve veri kaynakları aşağıda yer almaktadir.

Ticaret Dengesi $=f$ (reel döviz kuru, kişi başı milli gelir, doğrudan yabancı yatırım, reel faiz, kamu harcamaları) 
Tablo 1. Değişkenler ve Kaynakları

\begin{tabular}{|l|l|}
\hline Veri & Kaynak \\
\hline Reel Efektif Döviz Kuru & IMF, International Financial Statistics (IFS) \\
\hline Reel Faiz & World Bank, World Development Indicators \\
\hline $\begin{array}{l}\text { Doğrudan Yabancı Yatırımlar Net Girişleri (\% } \\
\text { GSYİH) }\end{array}$ & $\begin{array}{l}\text { IMF, International Financial Statistics and } \\
\text { Balance of Payments databases }\end{array}$ \\
\hline Dış Ticaret Dengesi & $\begin{array}{l}\text { World Bank national accounts data, and } \\
\text { OECD National Accounts data files }\end{array}$ \\
\hline Kamu Harcamaları (\% GSYİH) & World Bank, World Development Indicators \\
\hline Kişi Başı Milli Gelir & $\begin{array}{l}\text { World Bank national accounts data, and } \\
\text { OECD National Accounts datafiles }\end{array}$ \\
\hline
\end{tabular}

Reel Efektif Döviz Kuru: Oluşturulan modelde dış ticaret dengesi üzerinde önemli ölçüde etkisinin olması beklenmektedir. Reel Efektif Döviz Kuru, yurt dışında üretilen malların yurt içinde üretilenler cinsinden göreli fiyatını ifade etmekte olup, reel efektif kurun yükselmesi, ulusal paranın değer kaybetmesi anlamına gelmektedir. Böyle bir durum, ihraç mallarını yabancı para cinsinden daha ucuz; ithal malları ise ulusal para cinsinden daha pahalı hale getirmektedir.

Kişi Başına Milli Gelir: Bir ülkenin refah seviyesinin önemli bir göstergesi olan kişi başına milli gelirin artması, ithalatın gelir ile olan bağından ötürü ithal mallara olan talebi de artırarak dış ticaret dengesinin bozulmasına yol açabilecektir.

Doğrudan Yabancı Yatırımlar (\% GSYİH): Bir firmanın mal veya hizmet üretimine yönelik olarak başka bir ülkede üretim tesisi kurması ya da var olan bir tesisi satın alması olarak tanımlanabilecek olan kavram, portföy yatırımlarından farklı olarak bulunduğu ülkede sermaye transferi, teknoloji ve organizasyon aktarımı da sağlamaktadır. Doğrudan yatırımların üretimi artırıc bir etkiye sahip olması mevcut üretim kapasitesine ilave olması ya da var olan tesislerin satın alınmasına göre farklılaşabilmekle birlikte döviz gelirlerinde artış sağlayabilecektir. Ayrıca yapılan üretimin ithal girdi ile gerçekleştirilmesi ya da üretilen ürünlerin iç pazara veya ihracata yönelik olması da reel döviz kurları ile dış ticaret dengesini belirleyecektir. Dolayısıyla söz konusu değişkenin bağımlı değişken üzerindeki etkisi her iki yönde olabilecektir.

Kamu Harcamaları (\%GSYIH): Devletin kamu harcamalarında oluşan artışlar, borçlanma yoluyla finanse ediliyorsa, ekonomide toplam talebin artmasına; talep artışı ise ekonomi tam istihdam ya da tam istihdama yakın seviyede ise enflasyona yol açabilmektedir. Yükselen enflasyon, ihraç ürünlerinin fiyatlarını yükselterek ülkenin rekabet gücünü de olumsuz yönde etkileyerek ihracatın azalmasına ve ithalatın artmasına yol açabilecektir.

Reel Faiz Oranı: Nominal faiz oranının enflasyondan arındırılmış hali olarak tanımlanabilen ve nominal faiz oranından beklenen enflasyon oranının çıkarılması yoluyla hesaplanan reel faiz oranında oluşan bir artış, ülkeye yönelik fon akımlarını teşvik ederek ulusal paranın değer kazanmasına ve dolayısıyla ihracatın azalıp ithalatın artmasına sebep olabilecektir.

Dış Ticaret Dengesi: Ampirik analize yönelik olarak oluşturulan modelde Dış Ticaret Dengesi bağımlı değişken olarak yer almaktadır. Dış ticaret dengesi temel olarak ihracat ve ithalat arasındaki pozitif ya da negatif farkı ifade etmektedir. Eğer ihracat ithalattan fazla ise dış ticaret fazlası söz konusuyken aksi durumda ise dış ticaret açığı söz konusudur. Bağımsız değişkenlerin ilgili değişkeni ne oranda açıkladığı analiz edilmeye çalışılmıştır. 


\section{Ampirik Analiz}

Analize konu olan değişkenlere logaritmik transformasyon uygulandıktan sonra bir modelin sağlamlığı açısından önem taşıyan bazı istatistik varsayımların kontrol edilmesi düşünülmüştür. $\mathrm{Bu}$ açıdan ilk olarak sınanması gereken husus, modelde hata teriminin birbirini takip eder değerleri arasında bir ilişkinin (korelasyon) olmamasıdır. Otokorelasyon olarak tanımlanan bu ilişkinin varlığını araştırmak amacıyla Wooldridge Otokorelasyon Testi uygulanmıştır. Elde edilen sonuç aşağıdaki Tablo 2'de gösterilmiştir.

Tablo 2. Otokorelasyon (Wooldrige Testi)

$$
\begin{aligned}
& \text { Wooldridge test for autocorrelation in panel data } \\
& \text { Ho: nofirst order autocorrelation } \\
& \begin{array}{c}
F(1,8)=13.666 \\
\text { Prob }>F=0.0061
\end{array}
\end{aligned}
$$

Wooldridge test sonucuna göre H0 hipotezi reddedilerek otokolerasyon olduğu sonucuna ulaşılmıştır.

Bir modelin sağlamlığı açısından kontrolü gereken bir diğer problem de oluşturulan modelde çoklu doğrusallığın bulunup bulunmadığıdır. İki ya da daha çok bağımsız değişken arasında yüksek oranda bir ilişkinin varlığı anlamına gelen çoklu doğrusallığın olması modelin anlamlılığı açısından istenmeyen bir durumdur. Söz konusu problemin testi amaciyla Varyans Enflasyon Faktörü (VIF) kullanılmıştır. VIF değerinin 10'un üzerinde olması potansiyel çoklu doğrusallığın varlığına işaret olarak kabul edilebilecek olup; test edilmesine yönelik analiz sonucu aşağıda yer almaktadır (Tablo 3).

Tablo 3. Çoklu Doğrusallık Testi (VIF)

\begin{tabular}{|l|l|l|l|l|}
\hline Variable & VIF & $\begin{array}{l}\text { SQRT } \\
\text { VIF }\end{array}$ & Tolerance & $\begin{array}{l}\text { R } \\
\text { Squared }\end{array}$ \\
\hline lndtd & 1.14 & 1.07 & 0.8751 & 0.1249 \\
\hline lnredk & 1.32 & 1.15 & 0.7550 & 0.2450 \\
\hline lnrf & 1.21 & 1.10 & 0.8275 & 0.1725 \\
\hline lndyy & 1.17 & 1.08 & 0.8561 & 0.1439 \\
\hline lnkh & 1.60 & 1.26 & 0.6254 & 0.3746 \\
\hline lnkbmg & 1.37 & 1.17 & 0.7305 & 0.2695 \\
\hline MeanVIF & $\mathbf{1 . 3 0}$ & & \\
\hline
\end{tabular}

Elde edilen Varyans Enflasyon Faktörü (VIF) ortalama değeri 10'un oldukça altında olduğundan modelde çoklu doğrusallık bulunmadığı sonucuna ulaşılmıştır.

Oluşturulan bir modelde elde edilen sonuçların güvenilirliği açısından hata terimi varyansının sabit olması önem taşımaktadır. Hata terimi varyansının sabit olması (Homoskedasticity) 
tahminleyicilerin minimum varyanslı ve güvenilir olması anlamına geldiği için istenilen bir durumdur. Bu koşulun sağlanamaması ise değişir varyanslılık (Heteroskedasticity) olarak adlandırılmaktadır. Modelde değişir varyanslılık (Heteroskedasticity) gibi bir problemin var olup olmadığını tespit için Breush-Pagan Testi'ne başvurulmuştur. Aşağıdaki test sonucu elde edilmiştir (Tablo 4).

Tablo 4. Değişir Varyanslılığın Testi (Breush-Pagan Testi)

Ho: Sabit Varyans

Değişkenler: lnredk, lnrf, lndyy, lnkh, lnkbmg

$\operatorname{chi} 2(5)=52.53$

Prob $>$ chi $2=0.0000$

Sabit varyanslılığın sınandığı test sonucunda H0 hipotezi reddedilerek değişir varyanslılık bulunduğu gözlenmiştir. Modelde bulunan otokorelasyon ve değişir varyanslılık gibi problemler karşısında sağlam bir analiz sonucu elde etmeye yönelik olarak FGLS yöntemine başvurulmuştur. Analiz sonucu ve elde edilen regresyon denklemi aşağıda gösterilmiştir (Tablo 5).

Tablo 5. FGLS Regresyonu Tahmin Sonuçları

\begin{tabular}{|l|l|l|l|l|l|l|}
\hline lndtd & Coef. & Std. Err. & $\mathrm{z}$ & $\mathrm{P}>|\mathrm{z}|$ & $\mathbf{( 9 5 \% )}$ & $\begin{array}{l}\text { Conf. } \\
\text { Interval }]\end{array}$ \\
\hline lnredk & .6288792 & .0556852 & 11.29 & 0.000 & .5197381 & .7380202 \\
$\ln r f$ & -.1800655 & .02699 & -6.67 & 0.000 & -.232965 & -.127166 \\
$\operatorname{lndyy}$ & -.0183848 & .0068466 & -2.69 & 0.007 & -.031804 & -.0049656 \\
$\operatorname{lnkh}$ & -.5271815 & .0380659 & -13.85 & 0.000 & -.6017893 & -.4525738 \\
$\operatorname{lnkbmg}$ & -1.032923 & .116365 & -8.88 & 0.000 & -1.260994 & -.8048518 \\
\hline cons & 36.13049 & 1.170128 & 30.88 & 0.000 & 33.83708 & 38.4239 \\
\hline
\end{tabular}

$\mathrm{DTD}=36.13+0.63$ REDK $-0.18 \mathrm{RF}-0.018 \mathrm{DYY}-0.53 \mathrm{KH}-1.033 \mathrm{KBMG}$

Çalışmada seçili ülkeler için yapılan ampirik analiz sonucunda reel efektif döviz kurunun diş ticaret dengesini aynı yönde etkilediği görülmektedir. Buna karşılık, reel faiz, doğrudan yabancı yatırımlar, kamu harcamaları ve kişi başı milli gelir değişkenlerinin ise dış ticaret dengesini zıt yönde etkilemektedir. Ayrıca tüm bağımsız değişkenler istatistiksel olarak anlamlı olup; bağımlı değişkeni büyük oranda açılamaktadır. 


\section{SONUÇ ve ÖNERILER}

Günümüzde dış ticarette giderek artan serbestleşme ile birlikte döviz kurları dış ticaret dengesinin sağlanmasında en önemli belirleyicilerden birisi haline gelmiştir. Gelişmekte olan ekonomilerin daha yüksek bir büyüme oranına ulaşarak gelişmiş ülkeler ile aralarındaki farkı en aza indirebilmeleri için daha fazla sabit sermaye yatırımlarına ihtiyaç duymaktadırlar. Bu durum ilgili ülkelerde yapısal bir sorun olarak dış ticaret açıklarını beraberinde getirmektedir. Finansal serbestleşme ile birlikte kısa vadeli sermaye akımları artan diş ticaret açıklarının finansmanında daha hayati bir role sahip olmuştur. Ancak bu tip akımların niteliği itibariyle hızla ülkeden çıkabilmesi gelişmekte olan ülkelerde döviz arz yetersizliği problemleri ile kur istikrarsızlıklarını beraberinde getirebilmektedir.

Gelişmekte olan ülkelerde özellikle makro ekonomik istikrar açısından döviz kurlarının istikrarı ile dış denge açısından rekabetçi bir kur politikası izleme gerekliliği çoğu zaman kendi içinde çelişebilmektedir. Teorik olarak döviz kurundaki yükselmenin ihracatı teşvik edip, ithalatı caydırarak dış dengenin iyileşmesini kolaylaştırması beklenmektedir. Bu nedenle bazı ülkeler döviz kurlarını aktif bir ticaret politikası aracı olarak kullanabilmektedir. Ancak, ülke içinde üretilen ürünlerin yurt içi ve yurt dışı talep esneklikleri, ülkenin üretim karakteristiği, aynı ürünü üreten diğer ülkelerdeki fiyat ve döviz politikaları, üretimde kalite ve çeşitlilik gibi birçok değişken döviz kurlarının dış denge üzerindeki etkisini etkileyebilmektedir.

Oluşturulan model çerçevesinde reel efektif döviz kurları ile dış ticaret dengesi üzerinde etkili olabileceği düşünülen bazı makro ekonomik değişkenler yardımıyla gerçekleştirilen ampirik analizde 2009- 2018 yıları arasındaki dönem için ekonomik olarak birbirine yakın olduğu düşünülen 9 ülke (Türkiye, Rusya, İran, Gürcistan, Endonezya, Brezilya, Meksika, Paraguay ve Pakistan) ele alınmıştır. Dış ticaret dengesinin bağımlı değişken olarak yer aldığı çalışmada kişi başına milli gelir, doğrudan yabancı yatırımlar, kamu harcamaları, reel faiz, reel efektif döviz kurları ise bağımsız değişkenler olarak yer almıştır.

Oluşturulan modelin ampirik analiz sonuçlarına göre, reel efektif döviz kuru değişkeni dış ticaret dengesini yüksek oranda ve ayn yönde etkilemektedir. Elde edilen sonuç teorik olarak literatür bulgularıyla da uyumludur. Çünkü reel kurun yükselmesi ihraç mallarının yabancı para cinsinden ucuzlatarak ülkenin rekabet gücünü ve ihracatını artırırken, ithal mallarını ulusal para cinsinden pahalı hale getirerek dış ticaret dengesinin iyileşmesine katkı sağlayabilecektir.

Literatürde, reel faiz oranının yükselmesinin ülkeye kısa vadeli sermaye akımlarının girişini teşvik ederek reel döviz kurunun düşmesine ve ülkenin ulusal parasının değer kazanarak rekabet gücünün azalmasına yol açması beklenir. Dolayısıyla reel faiz oranının yükselmesinin dış ticaret dengesini negatif yönde etkilemesi beklenmektedir. Bu açıdan elde edilen sonuç teorik olarak beklenti ile uyumludur.

Oluşturulan modelde elde edilen bir diğer sonuç da Dış Ticaret Dengesi'nin anlamlılık düzeyi çok yüksek belirleyicilerinden bir diğerinin de Doğrudan Yabancı Yatırımlar değişkeni olduğudur. Bağımlı değişken ile arasında zıt yönlü bir ilişki olduğu görülmektedir. Bu durum ilgili ülkelere yönelik doğrudan yatırımların üretim kapasitesini artıran sabit sermaye yatırımları olmayıp hisse devri ya da portföy yatırımı amaçlı olabileceğini düşündürmektedir.

Benzer bir biçimde Kamu Harcamaları değişkeni, bağımlı değişkeni çok yüksek bir oranda açıklamakta ve bağımlı değişken olan dış ticaret dengesi ile arasında zıt yönlü bir ilişkinin söz konusu olduğu; diğer bir deyişle kamu harcamalarındaki artışın dış ticaret dengesini olumsuz yönde etkilediği görülmektedir. Bu nedenle, borçlanma yoluyla finanse edilen kamu harcamalarının ilgili ülkelerde ekonominin tam istihdama yakın bir seviyede olmasına bağlı 
olarak daha çok enflasyonist baskılara yol açarak ülkenin rekabet gücünü olumsuz etkilediği düşünülebilecektir.

Bir ülkenin refah seviyesinin önemli göstergelerinden olan Kişi başına milli gelir değişkeni ile bağımlı değişken arasında beklendiği gibi negatif yönlü bir ilişki söz konusu olup; değişkenin, bağımlı değişken olan dış ticaret dengesini yüksek bir oranda açıklamaktadır. İthalatın gelir ile olan bağlantısından dolayı ülkenin kişi başına milli gelirindeki artışın ithalatı artırıp; ihracatı azaltarak diş ticaret dengesini kötüleştireceği kabul edilebilecektir.

Finansal serbestleşme süreci ile birlikte gelişmekte olan ülkeler ekonomik büyüme ve kalkınma için gerekli sermaye birikiminin yetersizliği sorununu aşabilmek açısından önemli bir kaynağa sahip olmuşlardır. Özellikle Doğrudan yatırımlar şeklinde ülkeye giren sermaye akımları hızlı bir büyümenin yolunu açmıştır. Ancak para ve sermaye piyasalarında kısa vadede yüksek kazanç sağlayıp ülkeden çıkma eğilimindeki kısa vali sermaye hareketlerinin bu süreçte doğrudan yatırımlara göre daha büyük hacme ulaştığı ve bu akımların risk algısındaki değişmeye bağlı olarak hızla ülkeleri terk ederek finansal krizlerin yolunu aç九t̆ğ da görülmektedir. Özellikle döviz kurlarının otoriteler tarafından sabit tutulma çabalarının hem kısa vadeli sermaye girişini teşvik ettiği ve hem de krizlerin ortaya çıkışında başlıca etkenlerden biri olduğu da göze çarpmaktadır. Bu nedenle gelişmekte olan ülkelerde öncelikle cari dengeyi sağlamayı mümkün kılacak ekonomi politikalarının izlenmesi krizlere karşı ekonomileri daha koruyucu olabilecek ve istikrarlı bir ekonomik büyümenin yolunu açabilecektir.

\section{KAYNAKÇA}

Aygören, Y. (2014). Döviz Kuru Dış Ticaret İlişkisi Türkiye Örneği, (Yayımlanmış Yüksek Lisans Tezi), Kafkas Üniversitesi, Kars.

Alptekin, V. (2009). Türkiye'de Dış Ticaret-Reel Döviz Kuru İlişkisi: Vektör Otoregresyon (VAR) Analizi Yardımıyla Sınanması, Niğde Üniversitesi İIBF Dergisi, 2(2): 132-149.

Als, J., Bahmani and Oskooe, M. (1995). Do Devaluations Improve Or Worsen The Terms of Trade?, Journal of Economic Studies, 22(6): 16-25.

Arize Augustine, C. (1994). Cointegration Test of a Long-Run Relation Between the Real Exchange Rate and The Balance International Economic Journal, 8(3): 1-9.

Bahmani-Oskooe, M., and Niroomand, F. (1998). Long-Run Price Elasticities and The MarshallLerner Condition Revisited, Economics Letters, 61(1): 101-109.

Badinger, H., and Clairfontaine, A. F. (2018). Trade Balance Dynamics and Exchange Rates: in Search of the J-Curve Using A Structural Gravity Approach, Department of Economics Working Paper, 256.

Baldemir, E. ve Ayşe K. (2004). Develüasyon, Para, Reel Gelir Değişkenlerinin Dış Ticaret Üzerine Etkisinin Panel Data Yöntemiyle Türkiye İçin İncelenmesi, Dokuz Eylül Üniversitesi Sosyal Bilimler Dergisi, 6(4): 44-59.

Chaudhary, G. M., Hashmi, S. H., and Khan, M. A. (2016). Exchange Rate and Foreign Trade: A Comparative Study of Major South Asian And South-East Asian Countries, Procedia-Social and Behavioral Sciences, 230: 85-93.

Caramazza, F., and Jahangir A. (1998). Fixed or Flexible Getting the Exchange Rate Right in the 1990, Imf Publication Services, 13. 
Cooper, R. N. (1971). An Assessment of Currency Devaluation in Developing Countries, New Haven: Yale University Press.

Çiçek, S. (2006). Türkiye'de Döviz Kuru Sistemleri ve Politikalarının İhracata Etkileri (1980-2004), (Yayımlanmamış Yüksek Lisans Tezi), Dokuz Eylül Üniversitesi, İzmir.

Eichengreen, B. J. Hamann A. J., Mason, P. R., Bredenkamp, H., Johnston, R. B., Jadresic, E., and Ötker, İ. (1998). Exit Strategies Policy Options for Countries Seeking Greater Exchange Rate Flexibility, Occasional Paper, 168, 55.

Edwards, S. (1989). Real Exchange Rates, Devaluation and Adjustment: Exchange Rate Policy in Developing Countries, Cambridge, Ma: The MIT Press.

Göçer, İ., ve Elmas, B. (2013). Genişletilmiş Marshall-Lerner Koşulu Çerçevesinde Reel Döviz Kuru Değişimlerinin Türkiye'nin Dış Ticaret Performansına Etkileri: Çoklu Yapısal Kırılmalı Zaman Serisi Analizi, BDDK Bankacllk ve Finansal Piyasalar Dergisi, 7(1): 137-157.

Halıcıoğlu, F. (2007). The J-Curve of Turkish Bilateral Trade: A Cointegration Approach, Journal of Economic Studies, 34(2).

Hephaktan, E., Çınar, S., Dündar Ö., (2011). Türkiye'de Uygulanan Döviz Kuru Sistemlerinin Dış Ticaret ile İlişkisi, Akademik Araştırmalar ve Çalışmalar Dergisi. 3(5): 64.

İnan E. A., (2002). Kur Rejimi Tercihi ve Türkiye, Bankacılık Dergisi, 40, 43.

Karagöz, M., ve Doğan, Ç. (2005). Döviz Kuru Dış Ticaret İlişkisi: Türkiye Örneği, Fırat Üniversitesi Sosyal Bilimler Dergisi, 15(2): 219-228.

Kansu, A. (2006). Döviz Kuru Sistemleri ve Döviz Krizleri: Türkiye 1994 ve 2001 Krizleri (2. Baskı), İstanbul: Scala Yayıncilik.

Lane P. R., and Milesi-Ferretti, G. M. (2002). External Wealth, The Trade Balance, And The real exchange Rate, European Economic Review, 46: 1049-1071.

Lal, A. K., and Lowinger, T. C., (2002). The J-Curve: Evidence from East Asia, Journal of Economic Integration, 17(2): 397-415.

Liew, K. S., Lim, K. P., and Hussain, H. (2003). Exchange rate and trade balance relationship: The experience of ASEAN countries. International Trade, 307003, 1-11.

Mckinnon, R. I, and Pill, H. (1999). Exchange Rate Regimes for Emerging Markets: Moral Hazard and International Overborrowing, Oxford Review of Economic Policy, 15(3): 19-38.

Rose, A. K. (1991). The Role of Exchange Rates in A Popular Model of International Trade, Journal of International Economics, 30(3): 298-320.

Spitaller, E. (1980). Short-Run Effects of Exchange Rate Changes on Terms of Trade and trade balance, Imf Staff Papers, 27(2): 320-348.

Shirvani H., and Barry W. (1997). The Relationship Between the Real Exchange Rate And The Trade Balance: An Empirical Reassessment, International Economic Journal, 11(1): 39-50.

Okay, E., Baytar. R. A., ve Sarıdoğan, E. (2012). Türkiye Ekonomisinde Döviz Kurundaki Değişimlerin Cari İşlemler Dengesi Üzerindeki Etkileri, İktisat İşletme ve Finans, 27(310): 79-101.

Onafowora A. O. (2003). Exchange Rate And The Trade Balance in East Asia: Is There A J Curve?, Economics Bulletin, 5(18): 1-13. 
Öncel, A., ve İnal, V. (2016). Türkiye' de Reel Döviz Kuru ile Dış Ticaret Dengesi Arasındaki İlişki: 2000-2015 Dönemi İçin ARDL Modeli ile Ampirik Bir Analiz, Namık Kemal Üniversitesi, İktisadi ve İdari Bilimler Fakültesi, Balkan Sosyal Bilimler Dergisi, Özel sayı, 786-799.

Üstüner T. S., (2017). Gelişmekte Olan Ülkelerde Dış Ticaret Dengesini Belirleyen Faktörlerin Marshall Lerner Koşulu Çerçevesinde Analizi, Yayımlanmış Yüksek Lisans Tezi, İzmir Katip Çelebi Üniversitesi, İzmir.

Vergil, H., ve Erdoğan, S. (2009). Döviz Kuru-Ticaret Dengesi İlişkisi: Türkiye Örneği, ZKÜ Sosyal Bilimler Dergisi, 5(9): 35-57.

Yağcı, F. (2001). Choice of Exchange Rate Regimes for Developing Countries, World Bank-Africa Region Working Paper, 16.

Yamak R., ve Korkmaz A. (2005). Reel Döviz Kuru ve Dış Ticaret Dengesi İlişkisi, İstanbul Üniversitesi İktisat Fakültesi Ekonometri ve İstatistik Dergisi, 2, 11-29.

Yörük D. (2008), Teoride ve Uygulamada Dış Ticaret Hadleri ve Kalkınma İlişkisi, Yayımlanmamış Yüksek Lisans Tezi, Marmara Üniversitesi, İstanbul. 